Pacific Journal of Mathematics

A NOTE ON A PROBLEM OF FUCHS 


\title{
A NOTE ON A PROBLEM OF FUCHS
}

\author{
D. L. BOYER
}

In [1] Fuchs has asked (problem 3) the cardinality of the set of all pure subgroups of an Abelian group. The purpose of this paper is to settle the question for nondenumerable Abelian groups. $|A|$ will denote the cardinality of the set $A$.

TheOREM. Let $G$ be a nondenumerable Abelian group, and let $\mathscr{P}$ be the collection of all pure subgroups, $P$, of $G$ with $|P|=|G|$. Then $|\mathscr{P}|=2^{|G|}$.

Proof. Let $T$ be the torsion subgroup of $G$. If $|T|<|G|$, then $|G / T|=|G|$ and by a result of Walker [3, Theorem 4], $G / T$, and hence $G$, has $2^{|G|}$ pure subgroups of order $|G|$.

If $|T|=|G|$, then we write $T$ in the form $T=\sum_{i, \alpha} \oplus Z_{\alpha}\left(p_{i}^{\infty}\right) \oplus \sum_{p} \oplus R_{p}$, where the $R_{p}$ are reduced primary groups and $\sum_{i, \alpha} \oplus Z_{\alpha}\left(p_{i}^{\infty}\right)$ is the maximal divisible subgroup of $T$.

If the above decomposition of $T$ has $|G|$ summands then the theorem follows.

If the above decomposition has fewer than $|G|$ summands, then $\left|\Sigma_{p} \oplus R_{p}\right|=|G|$.

We first consider the case that there exists a prime, $p$, such that $\left|R_{p}\right|=|G|$. Let $B$ be a basic subgroup of $R_{p}$. If $|B|<\left|R_{p}\right|$, then $\left|R_{p}\right| B|=| G \mid$ and $R_{p} / B=\sum_{\alpha \epsilon_{A}} \oplus Z_{\alpha}\left(p^{\infty}\right)$ with $|A|=|G|$. Thus the theorem holds for $R_{p} / B$, and hence also for $G$. If $|B|=\left|R_{p}\right|$, then since $B$ is the direct sum of cyclic groups, $B=\sum_{\alpha \in A} \oplus C_{\alpha}$, it follows that $|A|=|G|$. Thus the theorem follows for $B$ and hence for $G$. Finally, if $\left|R_{p}\right|<|G|$ for all $p$, we let $R^{1}=\sum_{p_{i}} \oplus R_{p_{i}}$, where the sum is taken over all primes, $p_{i}$, such that $\left|R_{p_{i}}\right|>\boldsymbol{\aleph}_{0}$. Then $\left|R^{\prime}\right|=|G|=$ $\sum\left|R_{p_{i}}\right|$. We have proved above that for each $p_{i}, R_{p_{i}}$ has $2^{\left|R p_{i}\right|}$ pure subgroups, $P(i)$ of order $\left|R_{p_{i}}\right|$. For each $i$, choose $P(i) \subset R_{p_{i}}$ with $|P(i)|=\left|R_{p_{i}}\right|$. Then $P=\sum \oplus P(i)$ is a pure subgroup of $R^{\prime}$ with $|P|=\left|R^{\prime}\right|$, and the number of subgroups formed in this way is $2^{|\sigma|}$.

\section{REFERENCES}

1. L. Fuchs, Abelian groups, Hungarian Academy of Science (1958), Budapest.

2. W. Scott, Groups and cardinal numbers, Amer. J. Math., 74 (1952), 187-197.

3. E. Walker, Subdirect sums and infinite Abelian groups, Pacific J. Math., 9 (1959), 287-291.

\section{Fresno State College}

Received October 22, 1959.

1 This is exactly the method used by Scott, [2]. 



\section{PACIFIC JOURNAL OF MATHEMATICS}

\section{EDITORS}

David GILbarg

Stanford University

Stanford, California

\section{F. H. BRowneLL}

University of Washington

Seattle 5, Washington

\section{A. L. Whiteman}

University of Southern California Los Angeles 7, California

\section{J. PAIGe}

University of California

Los Angeles 24, California

\section{ASSOCIATE EDITORS}
E. F. BECKENBACH
T. M. CHERRY
D. DERRY

\author{
E. HEWITT \\ A. HORN \\ L. NACHBIN
}

\author{
M. OHTSUKA \\ H. L. ROYDEN \\ M. M. SCHIFFER
}

E. SPANIER

E. G. STRAUS

F. WOLF

\section{SUPPORTING INSTITUTIONS}

\author{
UNIVERSITY OF BRITISH COLUMBIA \\ CALIFORNIA INSTITUTE OF TECHNOLOGY \\ UNIVERSITY OF CALIFORNIA \\ MONTANA STATE UNIVERSITY \\ UNIVERSITY OF NEVADA \\ NEW MEXICO STATE UNIVERSITY \\ OREGON STATE COLLEGE \\ UNIVERSITY OF OREGON \\ OSAKA UNIVERSITY \\ UNIVERSITY OF SOUTHERN CALIFORNIA
}

\author{
STANFORD UNIVERSITY \\ UNIVERSITY OF TOKYO \\ UNIVERSITY OF UTAH \\ WASHINGTON STATE COLLEGE \\ UNIVERSITY OF WASHINGTON \\ AMERICAN MATHEMATICAL SOCIETY \\ CALIFORNIA RESEARCH CORPORATION \\ HUGHES AIRCRAFT COMPANY \\ SPACE TECHNOLOGY LABORATORIES \\ NAVAL ORDNANCE TEST STATION
}

\footnotetext{
Mathematical papers intended for publication in the Pacific Journal of Mathematics should be typewritten (double spaced), and the author should keep a complete copy. Manuscripts may be sent to any one of the four editors. All other communications to the editors should be addressed to the managing editor, L. J. Paige at the University of California, Los Angeles 24, California.

50 reprints per author of each article are furnished free of charge; additional copies may be obtained at cost in multiples of 50 .
}

The Pacific Journal of Mathematics is published quarterly, in March, June, September, and December. The price per volume (4 numbers) is $\$ 12.00$; single issues, $\$ 3.50$. Back numbers are available. Special price to individual faculty members of supporting institutions and to individual members of the American Mathematical Society: $\$ 4.00$ per volume; single issues, $\$ 1.25$.

Subscriptions, orders for back numbers, and changes of address should be sent to Pacific Journal of Mathematics, 2120 Oxford Street, Berkeley 4, California.

Printed at Kokusai Bunken Insatsusha (International Academic Printing Co., Ltd.), No. 6, 2-chome, Fujimi-cho, Chiyoda-ku, Tokyo, Japan.

PUBLISHED BY PACIFIC JOURNAL OF MATHEMATICS, A NON-PROFIT CORPORATION

The Supporting Institutions listed above contribute to the cost of publication of this Journal, but they are not owners or publishers and have no responsibility for its content or policies. 


\section{Pacific Journal of Mathematics}

\section{Vol. 10, No. $4 \quad$ December, 1960}

M. Altman, An optimum cubically convergent iterative method of inverting a linear bounded operator in Hilbert space . . . . . . . . . . . . . . . . . . . . . . . . . . 1107

Nesmith Cornett Ankeny, Criterion for rth power residuacity ................. 1115

Julius Rubin Blum and David Lee Hanson, On invariant probability measures I . . . . . 1125

Frank Featherstone Bonsall, Positive operators compact in an auxiliary topology ..... 1131

Billy Joe Boyer, Summability of derived conjugate series . . . . . . . . . . . . . . . . 1139

Delmar L. Boyer, A note on a problem of Fuchs . . . . . . . . . . . . . . . . . 1147

Hans-Joachim Bremermann, The envelopes of holomorphy of tube domains in infinite

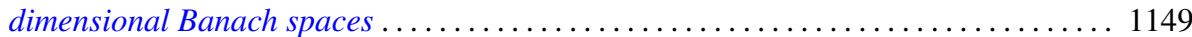

Andrew Michael Bruckner, Minimal superadditive extensions of superadditive

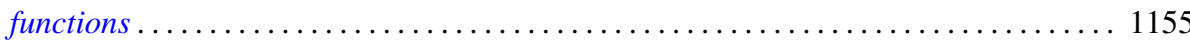

Billy Finney Bryant, On expansive homeomorphisms .................... 1163

Jean W. Butler, On complete and independent sets of operations in finite algebras . . . . . 1169

Lucien Le Cam, An approximation theorem for the Poisson binomial distribution ...... 1181

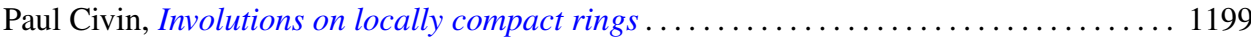

Earl A. Coddington, Normal extensions of formally normal operators . . . . . . . . . 1203

Jacob Feldman, Some classes of equivalent Gaussian processes on an interval ........ 1211

Shaul Foguel, Weak and strong convergence for Markov processes . . . . . . . . . . . 1221

Martin Fox, Some zero sum two-person games with moves in the unit interval ........ 1235

Robert Pertsch Gilbert, Singularities of three-dimensional harmonic functions . . . . . . . 1243

Branko Grünbaum, Partitions of mass-distributions and of convex bodies by

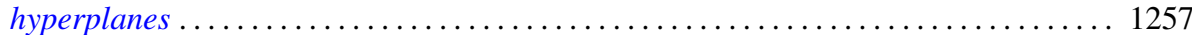

Sidney Morris Harmon, Regular covering surfaces of Riemann surfaces ........... 1263

Edwin Hewitt and Herbert S. Zuckerman, The multiplicative semigroup of integers

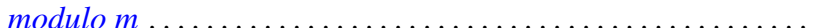

Paul Daniel Hill, Relation of a direct limit group to associated vector groups . ......... 1309

Calvin Virgil Holmes, Commutator groups of monomial groups . .

James Fredrik Jakobsen and W. R. Utz, The non-existence of expansive homeomorphisms

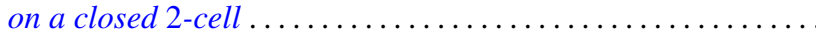

John William Jewett, Multiplication on classes of pseudo-analytic functions . . . . . . . 1323

Helmut Klingen, Analytic automorphisms of bounded symmetric complex domains . . . . 1327

Robert Jacob Koch, Ordered semigroups in partially ordered semigroups . . . . . . . . 1333

Marvin David Marcus and N. A. Khan, On a commutator result of Taussky and

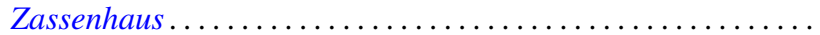

John Glen Marica and Steve Jerome Bryant, Unary algebras......

Edward Peter Merkes and W. T. Scott, On univalence of a continued fraction . . . . . . . 1361

Shu-Teh Chen Moy, Asymptotic properties of derivatives of stationary measures . . . . . 1371

John William Neuberger, Concerning boundary value problems . . . . . . . . . . . 1385

Edward C. Posner, Integral closure of differential rings . . . . . . . . . . . . . . . . . 1393

Marian Reichaw-Reichbach, Some theorems on mappings onto . . . . . . . . . . . . . 1397

Marvin Rosenblum and Harold Widom, Two extremal problems . . . . . . . . . . . . . . . . 1409

Morton Lincoln Slater and Herbert S. Wilf, A class of linear differential-difference

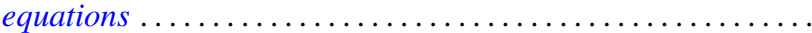

Charles Robson Storey, Jr., The structure of threads . . . . . . . . . . . . . . . . . . 1429

J. François Treves, An estimate for differential polynomials in $\partial / \partial z_{1},, \cdots, \partial / \partial z_{-} n \ldots \ldots 1447$

J. D. Weston, On the representation of operators by convolutions integrals . . . . . . . . 1453

James Victor Whittaker, Normal subgroups of some homeomorphism groups ......... 1469 